\title{
Source and strong-motion characteristics of two $M>6$ buried earthquakes in southwest Taiwan
}

\author{
Yi-Ying Wen ${ }^{1,2^{*}}$, Yin-Tung Yen ${ }^{3} \mathbb{B}$, Chun-Hsiang Kuo ${ }^{4}\left(\mathbb{0}\right.$ and Kuo-En Ching ${ }^{5}$
}

\begin{abstract}
We used near-field strong-motion data to investigate the complex combination of source effect and site response for two recent disastrous earthquakes in southwest Taiwan. We estimated strong-motion generation areas (SMGAs) of $2.8 \mathrm{~km} \times 2.8 \mathrm{~km}$ and $6.0 \mathrm{~km} \times 4.2 \mathrm{~km}$ in a frequency band of $0.4-10 \mathrm{~Hz}$ for the 2010 Jiashian and 2016 Meinong earthquakes, respectively. The high-stress drops of 26.2 and 17.0 MPa for these two buried events were potentially related to the small dimension and deep rupture. Our results revealed that both earthquakes exhibited westward rupture directivity, whereas the 2016 Meinong event exhibited a stronger directivity effect because of the consistency between the propagation and slip directions. The localized high peak ground velocity (PGV) patch and the nonlinear site response could be attributed to the soft sediment with high pore fluid pressure and low-velocity structure beneath this region. However, the greater seismic moment and closer faulting location to the thick-mudstone-layer region for the 2016 Meinong event reinforced the strong ground shaking and serious damage over the broad area. This implies that this thick-mudstone-layer region in southern Taiwan plays a crucial role in earthquake response, and an investigation of characteristic site effects should be conducted for seismic hazard mitigation.
\end{abstract}

Keywords: Rupture directivity, Strong motion generation area, Nonlinear site response

\section{Background}

Two disastrous events, the $M_{\mathrm{L}} 6.4$ Jiashian and $M_{\mathrm{L}} 6.6$ Meinong earthquakes at March 4, 2010, and February 5, 2016, respectively (Fig. 1), struck the foothill region in southern Taiwan, which has a very thick mudstone layer (Rau and Wu 1995). No $M>6$ events had been recorded in this region since 1901 (Chan and Wu 2012; Wen et al. 2016). These two buried, moderate-size events caused intense ground shaking ( $>400 \mathrm{gal}$ ) and resulted in unexpected disasters, especially the 2016 Meinong event, which induced widespread and serious damage.

Although these two events occurred on two sides of the north-south trending Chaochou fault (CCUF), focal mechanisms determined by the Global Centroid

\footnotetext{
*Correspondence: yiyingwen@gmail.com

${ }^{1}$ Department of Earth and Environmental Sciences, National Chung

Cheng University, Chia-yi County 62102, Taiwan

Full list of author information is available at the end of the article
}

Moment Tensor (CMT) indicated that both events ruptured on the northeast dipping fault plane with NW-SE strikes (Fig. 1). The observed peak ground acceleration (PGA) and aftershock distributions of the 2010 Jiashian and 2016 Meinong events both reflected the fault plane rupture toward the northwestern direction (Wu et al. 2011, 2016). Through joint inversion, Lee et al. (2013) and Huang et al. (2013) demonstrated that the 2010 Jiashian event was initiated at an approximate depth of $20 \mathrm{~km}$ and ruptured upward to a shallow depth; moreover, Lee et al. (2016), Huang et al. (2013), and Diao et al. (2018a) have revealed that in the 2016 Meinong event, faulting was initiated at a depth of nearly $15 \mathrm{~km}$ and was subsequently propagated to the down-dip region at a depth of approximately $20 \mathrm{~km}$ before being extended westward to form the major asperity.

The 2010 Jiashian event occurred at the border east of the mudstone layer, whereas the 2016 Meinong earthquake might have been located in the mudstone region 


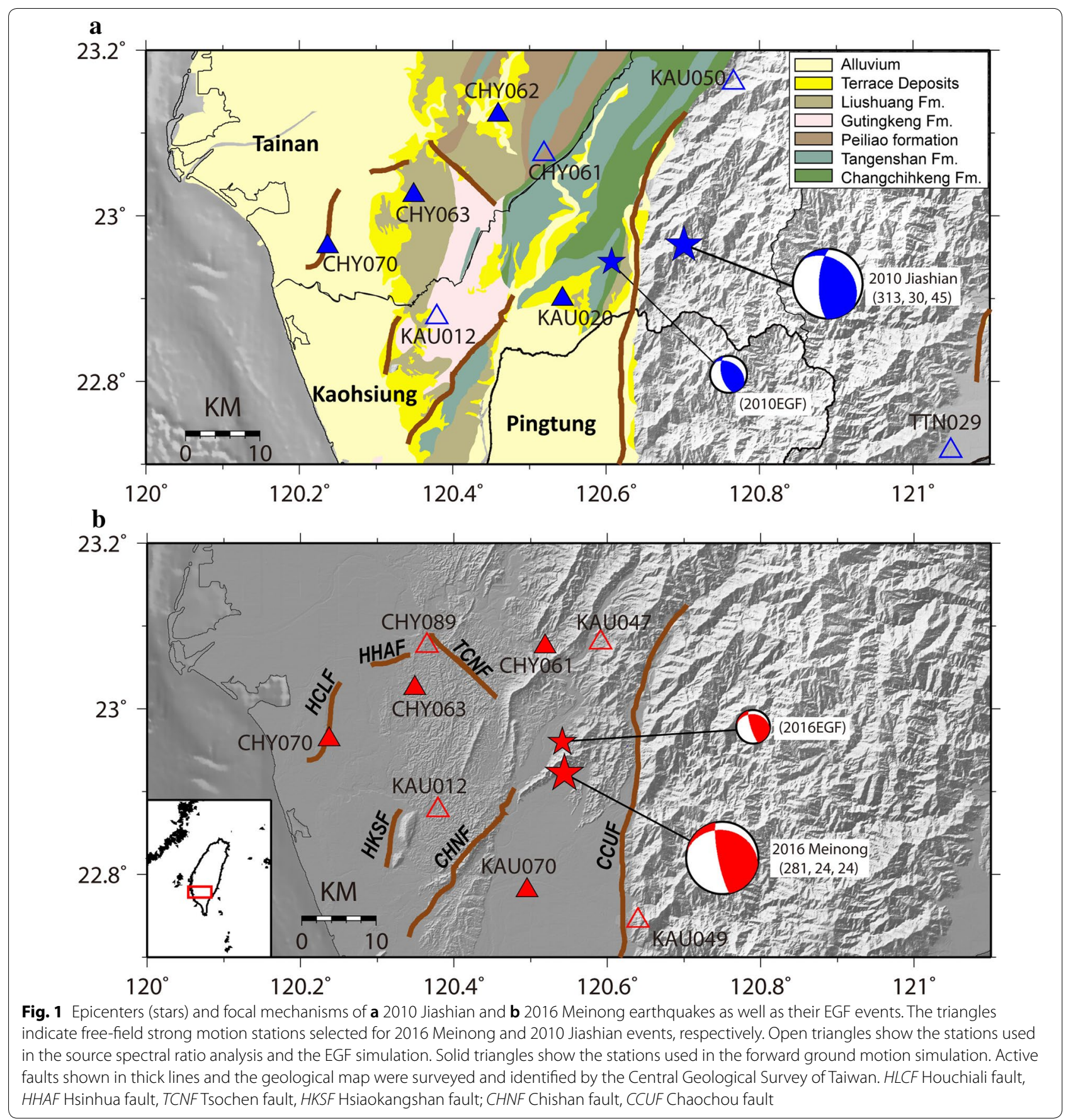

but adjacent to the site of the 2010 Jiashian event. However, the damage that resulted from the 2016 Meinong earthquake was much more serious than that resulting from the 2010 Jiashain event. Studies have suggested that the strong ground shaking during these two events might have been caused by several factors, including rupture directivity, radiation patterns, and site effects (Lee et al.
2013, 2016; Kanamori et al. 2017; Diao et al. 2018a, b; Lin et al. 2018). However, explanations involving interactions between these two events remain lacking; explanations have centered on individual considerations of the source and site effects of these events. Because many free-field strong-motion stations are constructed around the source area of the 2010 Jiashian and 2016 Meinong 
earthquakes, we had a good opportunity to comparatively investigate the source and site characteristics in the foothill region.

\section{Broadband strong-motion simulation}

The time-series of near-field seismic data were used to investigate source properties and ground shaking related to seismic damage. The empirical Green's function (EGF) method is a well-developed technique for analyzing the source properties of the broadband frequency (up to approximately $10 \mathrm{~Hz}$ ) after eliminating the influences of site response and the propagation path (e.g., Irikura 1986; Miyake et al. 2001, 2003). Considering the criteria for a suitable EGF, namely a smaller magnitude with a similar focal mechanism to the target event (Irikura 1986; Velasco et al. 1994), we selected the $M_{\mathrm{L}} 4.1$ event and $M_{\mathrm{L}} 4.6$ event on July 31,2010 , and May 2, 2010, respectively (Fig. 1; Table 1), as the EGFs of the 2010 Jiashian and 2016 Meinong earthquakes, respectively. The epicenters of the two target events and their EGFs were determined by Taiwan's Central Weather Bureau (CWB). Chen et al. (2019) obtained a strong-motion generation area (SMGA) model of the 2016 Meinong event on the NS-striking fault plane. However, most relevant studies (e.g., Huang et al. 2016; Lee et al. 2016; Chen et al. 2017; Kanamori et al. 2017; Diao et al. 2018a, b; Lin et al. 2018; Chen, 2019) have suggested an EW-striking rupture. We also considered the EW-striking fault plane for the 2016 Meinong event. The fault plane solutions were determined by the global CMT solution for two target events and by the broadband array in Taiwan for seismology (BATS) for two EGF events. In this study, we used freefield strong-motion records maintained by the CWB (Shin et al. 2013) and selected the stations according to the azimuthal coverage and waveform quality of both mainshock and EGF events (Fig. 1; Table 2).

By applying the source spectral ratio fitting approach and the weighted least-squares method (Miyake et al. 1999, 2003), we could fit the observed source spectral ratio of the target event to the EGF event with a theoretical function using the omega-squared source model of Brune (1970, 1971):

$$
\operatorname{SSRF}(f)=\frac{M_{0}}{m_{0}} \cdot \frac{1+\left(f / f_{\mathrm{ca}}\right)^{2}}{1+\left(f / f_{\mathrm{cm}}\right)^{2}},
$$

where $M_{0} / m_{0}$ is the seismic moment ratio of the target event to the EGF event at the lowest frequency, and $f_{\mathrm{cm}}$ and $f_{\text {ca }}$ are the corner frequencies of the target and EGF events, respectively. Subsequently, we applied the formulas of Irikura (1986) and Miyake et al. (2003):

$$
U_{0} / u_{0}=M_{0} / m_{0}=C N^{3}, \quad N=f_{\mathrm{ca}} / f_{\mathrm{cm}},
$$

where $U_{0} / u_{0}$ is the constant flat level ratio of the target event to the EGF event for the displacement spectra. We could then derive the scaling parameters $C$ and $N$, which are the ratios of stress drops and fault dimensions between the target event and EGF event, respectively. Considering the probable rupture directivity effect, four strong-motion stations surrounding the source region (open triangles in Fig. 1) for both events were chosen to calculate the observed source spectral ratio of the target event to the EGF event for the broadband frequency $(0.4-10 \mathrm{~Hz})$ with a 15 -s window, including the entire $\mathrm{S}$-wave. Figure 2 presents the observed and fitting spectral ratios of the 2016 Meinong event to the EGF one. Through the source spectral ratio fitting analysis, we obtained the scaling parameters $N$ and $C$.

We then applied the EGF method to estimate the SMGA, which represents the characteristic area with high slip velocity and a uniform stress drop within the total rupture area. The EGF method can reproduce the near-field strong ground motions for the broadband frequency. The SMGA is defined as $N \times N$ subfaults with dimensions equivalent to the rupture area of the EGF event (Irikura 1986; Irikura and Kamae 1994; Miyake et al. 2001). The rupture starting position of the SMGA was assumed based on the main asperity of the slip model

Table 1 Earthquake parameters for the 2010 Jiashian earthquake, 2016 Meinong earthquake and the related EGF Events

\begin{tabular}{lllll}
\hline Date & $\mathbf{0 4}$ Mar 2010 (Jiashian) & 31 Jul 2010 (2010 EGF) & 05 Feb 2016 (Meinong) & 02 May 2010 (2016 EGF) \\
\hline Epicenter & $120.701^{\circ} \mathrm{E}$ & $120.607^{\circ} \mathrm{E}$ & $120.544^{\circ} \mathrm{E}$ & $120.541^{\circ} \mathrm{E}$ \\
& $22.965^{\circ} \mathrm{N}$ & $22.945^{\circ} \mathrm{N}$ & $22.922^{\circ} \mathrm{N}$ & $22.960^{\circ} \mathrm{N}$ \\
Depth & $22.6 \mathrm{~km}$ & $17.1 \mathrm{~km}$ & $14.6 \mathrm{~km}$ & $18.4 \mathrm{~km}$ \\
$\begin{array}{l}\text { Fault plane (strike, } \\
\quad \text { dip, rake) }\end{array}$ & $313 / 30 / 45^{\mathrm{a}}$ & $299 / 17 / 40^{\mathrm{b}}$ & $281 / 24 / 24^{\mathrm{a}}$ & $286 / 24 / 33^{\mathrm{b}}$ \\
$M_{\mathrm{L}}$ & 6.4 & 4.7 & 6.6 & 4.6 \\
$\mathrm{M}_{0}$ & $3.02 \times 10^{18} \mathrm{Nm}^{\mathrm{a}}$ & $4.66 \times 10^{15} \mathrm{Nm}^{\mathrm{b}}$ & $5.25 \times 10^{18} \mathrm{Nm}^{\mathrm{a}}$ & $7.54 \times 10^{15} \mathrm{Nm}^{\mathrm{b}}$
\end{tabular}

The epicenters were determined by CWB and Global CMT solution, respectively. The fault plane solutions and seismic moment were determined by ${ }^{\text {a }}$ Global CMT and ${ }^{\mathrm{b}}$ BATS solution, respectively 
Table 2 Observed PGA values for the 2010 Jiashian and 2016 Meinong earthquakes

\begin{tabular}{|c|c|c|c|c|c|c|c|c|c|c|c|}
\hline \multirow[t]{3}{*}{ Station } & \multirow[t]{3}{*}{ Lon $\left({ }^{\circ} \mathrm{E}\right)$} & \multirow[t]{3}{*}{ Lat $\left({ }^{\circ} \mathrm{N}\right)$} & \multirow[t]{3}{*}{ Vs30 (m/s) } & \multicolumn{4}{|c|}{2010 Jiashian } & \multicolumn{4}{|c|}{2016 Meinong } \\
\hline & & & & \multicolumn{3}{|c|}{ PGA (gal) } & \multirow[t]{2}{*}{$\overline{\mathrm{DNL}^{\mathrm{a}}}$} & \multicolumn{3}{|c|}{ PGA (gal) } & \multirow[t]{2}{*}{$\mathrm{DNL}^{\mathrm{b}}$} \\
\hline & & & & UD & NS & EW & & UD & NS & EW & \\
\hline CHY060 & 120.2460 & 23.1239 & 223.92 & & & & & 79.10 & 170.76 & 237.26 & \\
\hline CHY061 & 120.5190 & 23.0745 & 500 & 99.90 & 179.38 & 169.38 & 3.91 & 134.70 & 209.16 & 316.68 & 4.07 \\
\hline CHY062 & 120.4590 & 23.1217 & 597.85 & 85.74 & 463.02 & 221.42 & & 132.26 & 444.54 & 426.22 & \\
\hline CHY063 & 120.3490 & 23.0250 & 287.66 & 71.24 & 174.66 & 385.18 & 3.93 & 163.26 & 238.64 & 416.92 & 3.58 \\
\hline CHY064 & 120.2418 & 23.0020 & 352 & & & & & 86.64 & 112.72 & 136.94 & \\
\hline CHY065 & 120.3516 & 22.9042 & 222.69 & 62.70 & 104.14 & 127.48 & & 121.70 & 165.92 & 161.90 & \\
\hline CHY067 & 120.1923 & 22.9975 & 229.04 & 38.36 & 83.32 & 93.76 & & 77.76 & 147.14 & 207.74 & \\
\hline CHY070 & 120.2365 & 22.9631 & 228.67 & 63.96 & 94.08 & 100.98 & 4.28 & 166.32 & 153.04 & 250.12 & 10.71 \\
\hline CHY078 & 120.2367 & 23.0380 & 162.25 & 25.30 & 61.54 & 101.66 & & 43.60 & 101.86 & 143.86 & \\
\hline CHY089 & 120.3646 & 23.0755 & 396.20 & 60.22 & 172.14 & 268.80 & 4.53 & 102.86 & 282.92 & 394.52 & 5.29 \\
\hline CHY097 & 120.2115 & 23.0090 & 341 & & & & & 48.02 & 125.36 & 127.46 & \\
\hline CHY116 & 120.1167 & 23.0768 & 194.34 & & & & & 55.52 & 115.86 & 166.10 & \\
\hline CHY118 & 120.4846 & 23.1824 & 308 & 76.30 & 245.82 & 261.86 & & 47.56 & 169.58 & 145.84 & \\
\hline CHY131 & 120.3611 & 23.1190 & 458 & 141.80 & 140.68 & 177.22 & & 167.62 & 260.50 & 263.14 & \\
\hline KAU012 & 120.3792 & 22.8778 & 304.66 & 37.84 & 95.18 & 110.58 & 3.20 & 93.86 & 180.08 & 210.66 & 4.03 \\
\hline KAU047 & 120.5906 & 23.0804 & 463 & & & & & 70.46 & 195.40 & 191.76 & \\
\hline KAU049 & 120.6401 & 22.7442 & 933 & 58.04 & 105.26 & 88.42 & & 69.93 & 102.29 & 61.30 & \\
\hline KAU068 & 120.5443 & 22.9759 & 813.23 & & & & & 97.16 & 216.86 & 184.00 & \\
\hline MTN155 & 120.6730 & 23.0734 & 413 & 86.74 & 276.54 & 272.42 & & 46.58 & 93.92 & 98.82 & \\
\hline KAU020 & 120.5430 & 22.8997 & 344.21 & 106.26 & 217.48 & 228.06 & & 106.46 & 203.56 & 181.42 & \\
\hline KAU070 & 120.4958 & 22.7809 & 289.39 & 40.06 & 81.04 & 102.04 & & 29.54 & 69.24 & 50.48 & \\
\hline TTN029 & 121.0490 & 22.7165 & 519.26 & 77.10 & 82.86 & 129.42 & & 9.58 & 11.20 & 9.84 & \\
\hline KAU050 & 120.7658 & 23.1607 & 651 & 64.28 & 113.08 & 84.82 & & 22.48 & 51.64 & 55.82 & \\
\hline
\end{tabular}

The DNL value are calculated by a: our study and b: Chen et al. (2017), respectively

(Poiata et al. 2012). Because the main asperity of the 2010 Jiashian earthquake was close to the hypocenter (Lee et al. 2013; Huang et al. 2013), we set the starting point at the CWB hypocenter. By contrast, the main slip patch of the 2016 Meinong earthquake was located approximately $10 \mathrm{~km}$ northwest of the epicenter (Huang et al. 2016; Lee et al. 2016; Diao et al. 2018a). Using a sourcescanning algorithm (SSA) technique and the seismic records of local dense networks without any filter, Lin et al. (2018) suggested double sources during the 2016 Meinong earthquake with the later and larger one being the mainshock, which was close to the finite-fault centroid of the joint inversion (Lee et al. 2016). We adopted this mainshock centroid determined using the SSA technique, which was at $120.5^{\circ} \mathrm{E}$ and $23.025^{\circ} \mathrm{N}$ with a depth of $15 \mathrm{~km}$, as the starting point for the 2016 Meinong event. Through grid search, the parameters related to the SMGA were then determined by minimizing the fitting residuals of displacement records and the acceleration envelopes (Miyake et al. 1999), as listed in Table 3.

Despite the differences in the attenuation and path effects between the target and EGF events, Figs. 3a and 4a reveal that the SMGA model of both events effectively explained the ground motion at stations used for the source spectral ratio analysis (open triangles in Fig. 1). Furthermore, Figs. $3 \mathrm{~b}$ and $4 \mathrm{~b}$ depict the waveform fitting of other stations (solid triangles in Fig. 1) whose data were not employed in the source spectral ratio fitting procedure for both events. The fitted waveforms were then used for validation through forward modeling, with the derived parameters presented in Table 3. The figures indicate that most features of the observed records in the broadband frequency range could be well reproduced, including the long-period ground motion pulses. Figure 5 presents the observed peak ground velocity (PGV) distribution and the SMGA model of the 2010 Jiashian and 2016 Meinong earthquakes, respectively. The starting points of both events were located around the eastern bottom corner of the SMGA, which corresponds to the westward propagation for both events and agrees with the PGV distribution as well as with the results of relevant studies (Wu et al. 2011, 2016; Huang et al. 2013, 2016; Lee et al. 2013, 2016; Kanamori et al. 2017; Diao et al. 2018a, b; Lin et al. 2018). The source patterns 


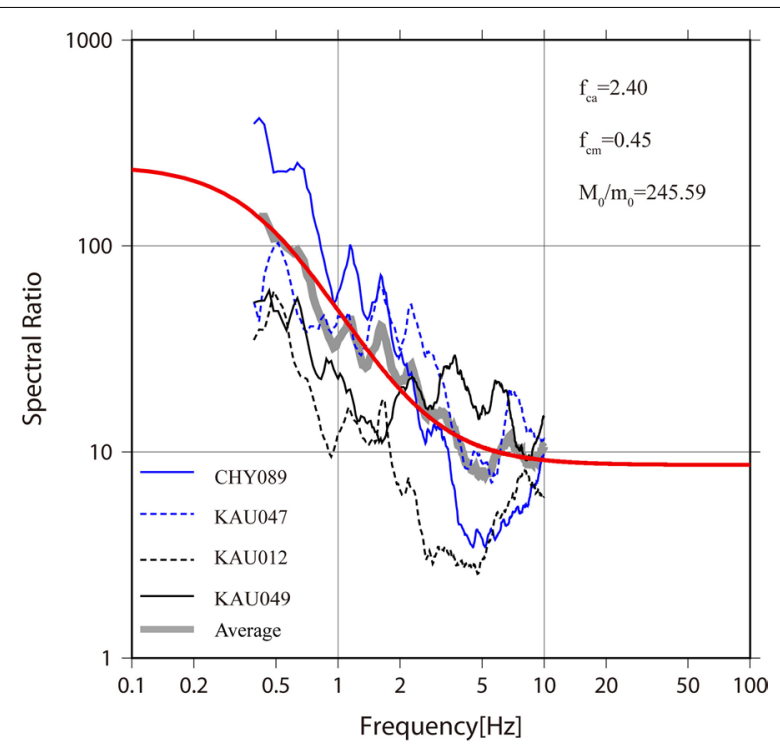

Fig. 2 Source spectral ratios of the mainshock to the EGF event, and average observed source spectral ratios (thick gray line) and fitting source spectral ratio function (red line) for the 2016 Meinong event. The values of the parameters determined from the source spectral ratio fitting are listed

(Huang et al. 2013; Lee et al. 2013; Fig. 5) indicated that the 2010 Jiashian earthquake mainly ruptured with an up-dip movement, which agrees with the minimal directivity effect (Aagaard et al. 2004). Conversely, the 2016 Meinong event was dominated by a westward leftlateral strike-slip motion (Huang et al. 2016; Lee et al. 2016; Fig. 5), and this propagation direction agrees with the slip direction during the fault rupture, satisfying the condition of the stronger rupture directivity effect (Aagaard et al. 2004).

\section{Time-frequency analysis}

Although the 2010 Jiashian event occurred only $20 \mathrm{~km}$ east of the 2016 Meinong event and also exhibited the rupture directivity effect (Wu et al. 2011; Lee et al. 2013), it did not draw any attention to the pulselike velocity ground motion as observed for the 2016 Meinong event (Diao et al. 2018a, b; Lin et al. 2018). The near-source long-period ground motion pulses were primarily contributed by the forward rupture directivity effect, which would strengthen pulses with periods longer than $0.6 \mathrm{~s}$, a feature usually clearly observed in velocity and displacement records, becoming nonsignificant in acceleration records (Poiata et al. 2017; Somerville et al. 1997). To analyze the time-varying frequency content of these near-field strong-motion records, we further adopted the S-transform technique (Stockwell et al. 1996), which combines the properties of shorttime Fourier transform as well as the wavelet transform. Figure 6 presents the unfiltered strong-motion records and normalized energy spectral density (ESD) of the stations used for strong-motion simulations. An examination of the unfiltered seismograms revealed significantly long-period ground motion pulses with the main energy concentrating around $1 \mathrm{~Hz}$ at stations CHY063, CHY070, and CHY089 for the 2016 Meinong event. These stations are located in the rupture-forward direction indicated by the result of the strong-motion simulation. Conversely, for the 2010 Jiashian event, only station CHY063 exhibited strong energy at approximately $1 \mathrm{~Hz}$, and the other stations revealed energy peaks of a higher frequency, which could reach $10 \mathrm{~Hz}$.

Table 3 Parameters of SMGA for the 2010 Jiashian and 2016 Meinong Earthquakes determined by the Strong Ground Motion Simulation, respectively

\begin{tabular}{|c|c|c|c|c|c|c|c|c|c|c|}
\hline & $N$ & $C$ & $\begin{array}{l}\text { Rupture starting } \\
\text { point }^{\mathrm{a}} / \text { depth }\end{array}$ & $L^{\mathbf{b}}(\mathrm{km})$ & $W^{c}(\mathrm{~km})$ & $V_{\mathrm{r}}(\mathrm{km} / \mathrm{s})$ & $\tau^{d}(s)$ & $S^{\mathrm{e}}\left(\mathrm{km}^{2}\right)$ & SMGA $\left(\mathrm{km}^{2}\right)$ & $\Delta \sigma_{\mathrm{SMGA}}{ }^{\mathrm{f}}(\mathrm{MPa})$ \\
\hline $\begin{array}{l}2010 \\
\text { Jiashian }\end{array}$ & 4 & 4.43 & $(3.4) / 22.6 \mathrm{~km}$ & 2.8 & 2.8 & 2.81 & 0.32 & $1287^{9}$ & 7.84 & 26.2 \\
\hline $\begin{array}{l}2016 \\
\text { Meinong }\end{array}$ & 6 & 1.62 & $(1.3) / 15.0 \mathrm{~km}$ & 6.0 & 4.2 & 2.75 & 0.66 & $891^{h}$ & 25.2 & 17.0 \\
\hline
\end{tabular}

a Rupture starting point defined as initiation number of $N$ along the strike and dip, respectively; ${ }^{\mathrm{b}}$ Length; ${ }^{\mathrm{C}}$ Width of the SMGA; ${ }^{\mathrm{d}}$ Rise time for the target event; ${ }^{\mathrm{e}}$ Total rupture area estimated from different studies according to Somerville et al. (1999); ${ }^{\mathrm{f}}$ Stress drop of the SMGA. The rupture models were adopted from, ${ }^{9}$ Lee et al. (2013); ${ }^{\text {h }}$ Lee et al. (2016)

(See figure on next page.)

Fig. 3 Comparison of observed (black lines) and synthetic (red lines) waveforms of 2010 Jiashian earthquake at strong motion stations used for a the source modeling through the empirical Green's function method (open triangles in Fig. 1a) and $\mathbf{b}$ forward ground motion simulations (solid triangles in Fig. 1a). The maximum amplitudes (max. Amp.), and the cross-correlation coefficient (CC) and residual (Res.) between the synthetic and observed data are shown above the traces. The residual between the observed and synthetics for the envelope of the acceleration (Res_env) is also shown. "obs" shows the observed record, "syn" shows the simulation 

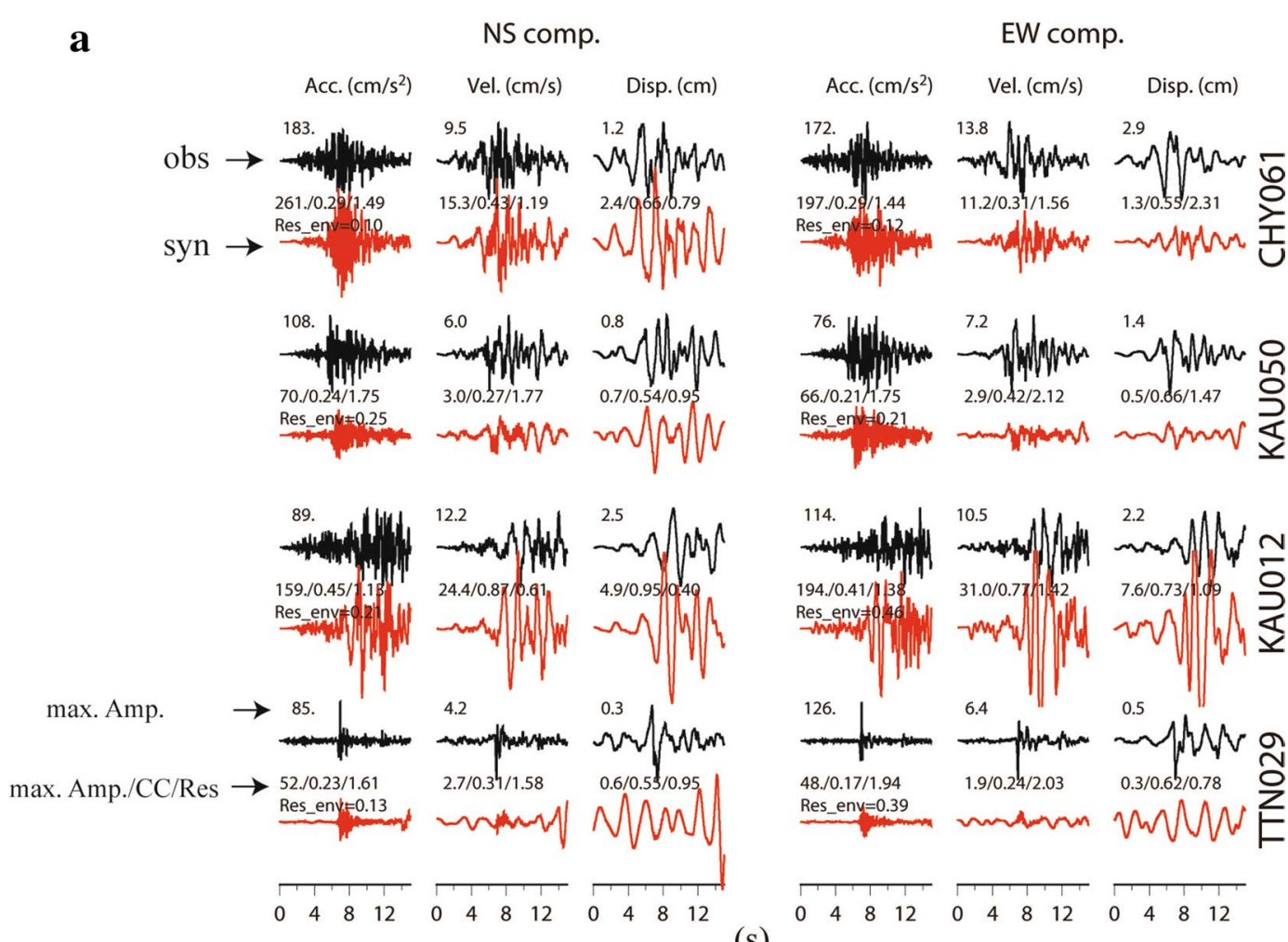

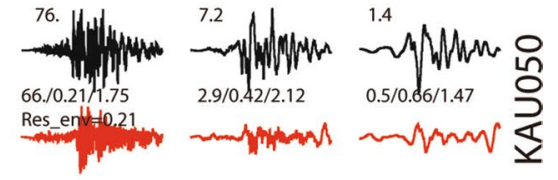
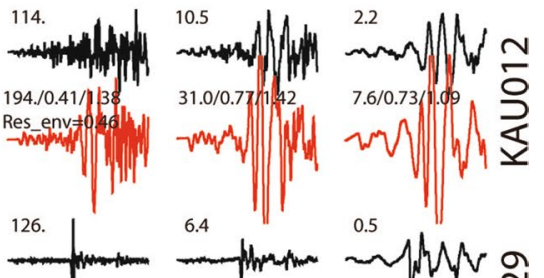

$6.4 \quad 0.5$

48./0.17/1.94 Res_eny $=0.39$

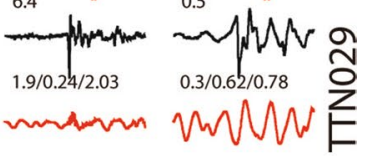

(s)

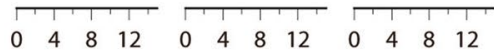

b
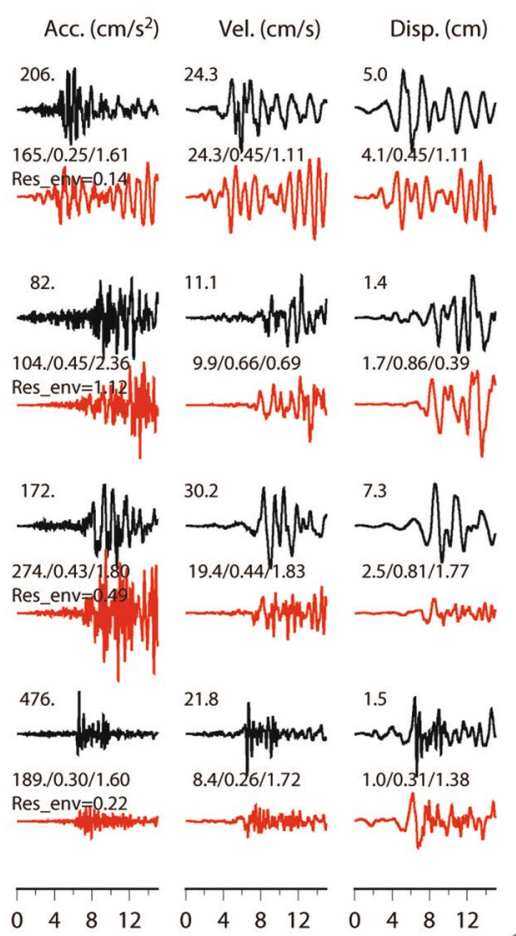

EW comp.
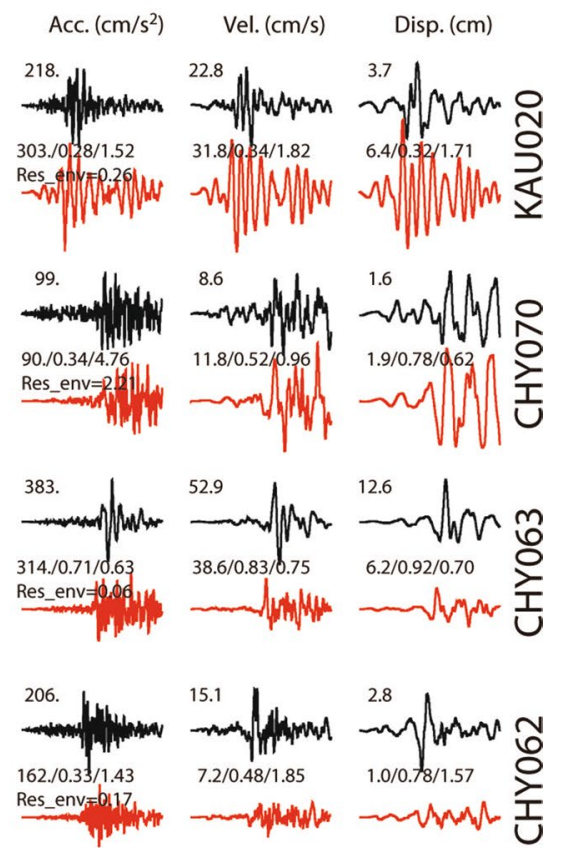

\begin{tabular}{lllllllllllll}
\hline & & 4 & 8 & 12 & 0 & 4 & 8 & 12 & 0 & 4 & 8 & 12
\end{tabular} 
This indicated that the broader area experienced longperiod strong ground motion during the 2016 Meinong earthquake.

\section{Discussion \\ Strong ground shaking intensified by high-stress drops of deep-buried ruptures}

Although the 2010 Jiashian and 2016 Meinong earthquakes were both moderate-sized blind-fault events, the strong ground acceleration reached $>400$ gal. Cotton et al. (2013) demonstrated that PGA is proportional to stress drop, and Radiguet et al. (2009) and Somerville (2003) found that the buried faults strengthen strong ground shaking, especially for a period range of approximately 1 s. Moreover, Wen et al. (2017) revealed that moderate blind-fault earthquakes in the Nantou area of Taiwan exhibit focal-depth dependence and a high-stress drop. In this study, we calculated the stress drops in the SMGA for the 2010 Jiashian and 2016 Meinong events and obtained the values of 26.2 and 17.0 MPa (Table 3), respectively; Fig. 7 reveals that these two events have a similar empirical relationship with the blind-fault events in the Nantou area, with stress drops being generally high and slowly increasing with depth. The major asperities of the 2010 Jiashian and 2016 Meinong earthquakes both developed at a deep region of approximately $20 \mathrm{~km}$ in depth (Huang et al. 2013, 2016; Lee et al. 2013, 2016; Diao et al. 2018a), and we derived small SMGAs of 7.84 and $25.2 \mathrm{~km}^{2}$ for these two events (Table 3). This is consistent with the conclusion of Kagawa et al. (2004) that buried events rupture a smaller area with larger stress drop correlating with depth.

\section{Localized high PGV attributed to soft-sediment amplification}

Field investigations have identified multiple types of disasters, including damaged or destroyed buildings and liquefaction features, as shown in Fig. 5, which exhibited a scattered distribution for the 2010 Jiashian event (Sung et al. 2010; Huang 2013) but were widespread for the 2016 Meinong event (Rau 2017). Wu et al. (2016) revealed that the observed high PGA and PGV regions caused by the 2016 Meinong earthquake were both located northwest of the epicenter; however, the distribution of damaged structures was more consistent with a high PGV pattern (Fig. 5). Furthermore, Lin et al. (2018) suggested that the disastrous damage in the Tainan City area might have mainly been caused by ground motions with a pulse-like velocity, which were mostly attributed to rupture directivity and site effects. Researchers widely recognize that the site amplification effect, such as soil layering and basin geometry, can enlarge seismic motions at the surface as well as subsequent damage (Bard and Bouchon 1985). Figure 5 reveals that both events exhibited their maximum PGV patch in almost the same region between the Hsinhua fault (HHAF) and Tsochen fault (TCNF). Kuo-Chen et al. (2017) deployed a dense seismic array immediately after the 2016 Meinong earthquake, and their data revealed a relatively low $\mathrm{S}$-wave speed pattern at depths of $0-1.5 \mathrm{~km}$ under this high PGV region, which could be related to soft-sediment amplifications. In addition, a large portion of the rupture area for the 2016 Meinong earthquake was beneath this thick-mudstonelayer region and radiated greater seismic energy (Huang et al. 2016; Lee et al. 2016; Fig. 5; Diao et al. 2018a), which could reinforce the strong ground shaking attributed to the focusing effect for the hanging-wall sites (Poiata et al. 2017).

To understand the properties and behaviors of strong motion for the near-source areas of the 2010 Jiashian and 2016 Meinong events, we applied time-frequency analysis to more stations, as shown in Fig. 6. Using $1.67 \mathrm{~Hz}$ as the bound, we separated strong-motion stations into two groups based on the dominant frequency band of energy bursts into a low-frequency band $(\mathrm{LF}, \leq 1.67 \mathrm{~Hz}$; regular triangles in Fig. 5) and high-frequency band (HF, $>1.67 \mathrm{~Hz}$; inverted triangles in Fig. 5). The analysis revealed that the high $\mathrm{PGV}$ region $(\mathrm{PGV}>30 \mathrm{~cm} / \mathrm{s})$ of the 2016 Meinong event not only agreed well with the distribution of damaged structures but also with LF-energy ground shaking (regular triangles in Fig. 5). Moreover, it could be noticed that the liquefactions also occurred within the high PGV region for both the 2010 Jiashian and 2016 Meinong events. Boore et al. (1989) indicated that PGA could be reduced through deamplification by the nonlinear soil effect, and Chen et al. (2017) demonstrated that the liquefactions caused by the 2016 Meinong event were located in a region with a significant reduction in PGA. Several studies have suggested that the relatively low-velocity region is beneath the significant coseismic uplift region of the 2016 Meinong event, which could be controlled by the high pore fluid pressure within

\footnotetext{
(See figure on next page.)

Fig. 4 Comparison of observed (black lines) and synthetic (red lines) waveforms of 2016 Meinong earthquake location at strong motion stations used for $\mathbf{a}$ the source modeling through the empirical Green's function method (open triangles in Fig. 1b) and $\mathbf{b}$ forward ground motion simulations (solid triangles in Fig. 1b). The maximum amplitudes (max. Amp.), and the cross-correlation coefficient (CC) and residual (Res.) between the synthetic and observed data are shown above the traces. The residual between the observed and synthetics for the envelope of the acceleration (Res_env) is also shown. "obs" shows the observed record, "syn" shows the simulation
} 


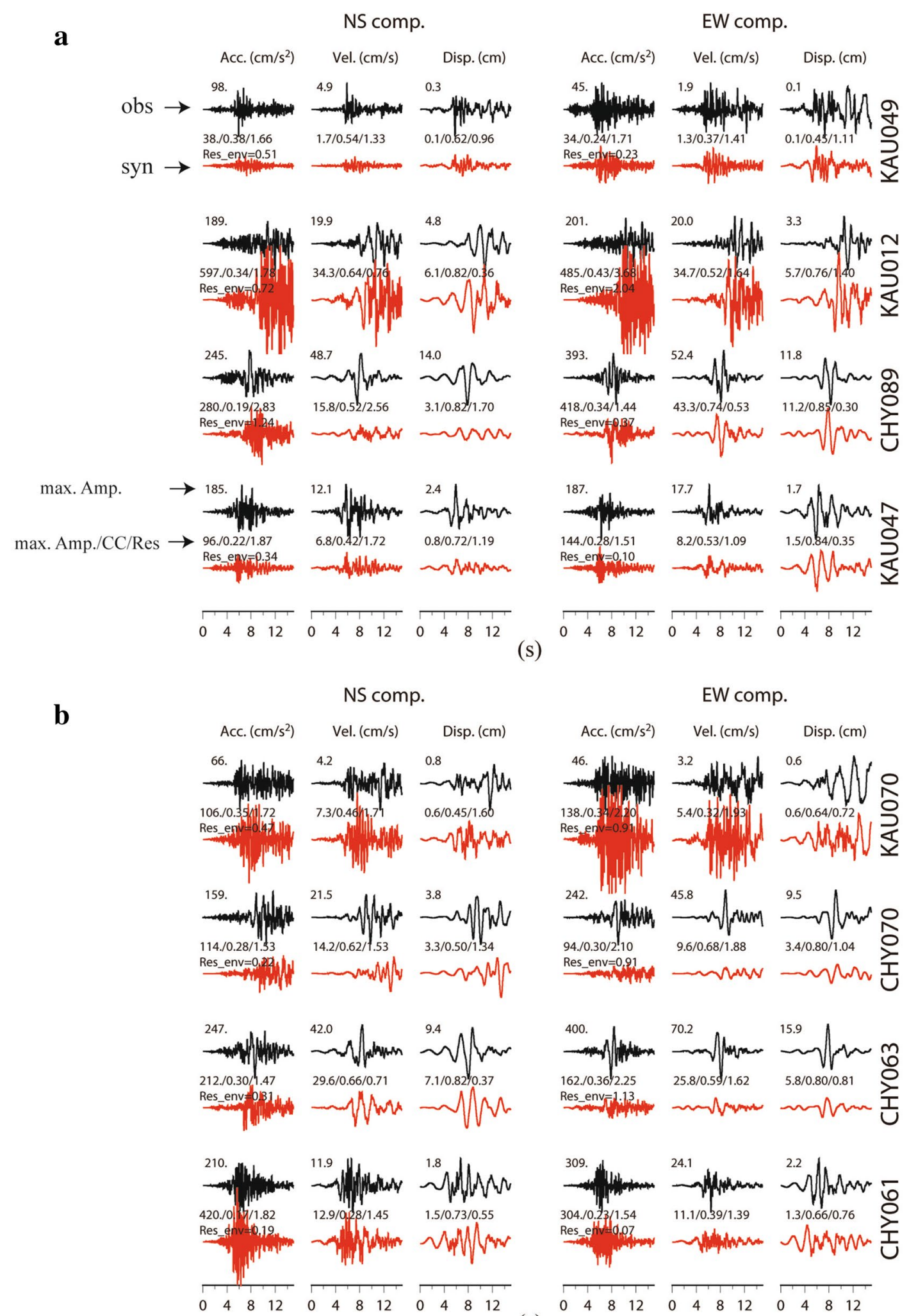

(s) 
the Liushuang, Erhchungli, and Gutingkeng Formations as well as by a relic onshore mud diapir beneath those formations (Yuan et al. 1987; Huang et al. 2004, 2014; Kuo-Chen et al. 2017). These soft materials do not result in the accumulation of strain and can be easily deformed once forces are applied to the region. Such conditions are similar to those at sites where nonlinear soil behavior has been found (Iai et al. 1995; Bonilla et al. 2005, 2011), and the distribution of LF-energy stations coincides with this soft-material region.

\section{Linear versus nonlinear site response}

Because the EGF simulations are based on the linear scaling of the seismic source, the nonlinear site response could be the factor that the synthetics could not explain the observed waveforms for some stations. As indicated in Fig. 2, stations CHY089 and KAU012 both displayed a significantly low spectral ratio in the high-frequency band, which might be related to deamplification due to the nonlinear site effect (Beresnev and Wen 1996; Boore et al. 1989). Chen et al. (2017) calculated the degree of nonlinearity (DNL) for the 2016 Meinong event, with the frequency range of $0.5-20 \mathrm{~Hz}$. The rupture-forward stations CHY063, CHY089, and CHY070 represent the relative low, medium, and maximum DNL with values of 3.58, 5.29, and 10.71 (red lines in Fig. 8), respectively. The horizontal to vertical spectral ratio (HVSR) of the 2016 Meinong earthquake indeed indicated deamplification in the high-frequency band; however, it also revealed amplification in the low-frequency part, especially around $1 \mathrm{~Hz}$. This was consistent with the time-frequency analysis (Fig. 6) and could be the factor causing the underestimation of synthetic waveforms for low-frequency content at these three stations. Following Chen et al. (2017), we calculated the DNL at some stations for the 2010 Jiashian event (blue lines in Fig. 8), which was roughly low with values between 3.2 and 4.6. The HVSR of the 2010 Jiashian earthquake indicated amplification in the lowfrequency band at station $\mathrm{CHY} 063$, which corresponded to the time-frequency analysis (Fig. 6) and the underestimation of synthetic waveforms for low-frequency content (Fig. 3b). For the two mainshocks, the basic information of the stations used-namely station coordinates, Vs30 (Kuo et al. 2012, 2017), PGA, and DNL-are listed in Table 2. For the DNL computation, we used the five stations located in the region of strong ground motion to check the soil nonlinearity. Figure 8 . reveals that the HVSR of weak motion displayed a clear dominant peak at stations CHY061, CHY070, and KAU012. CHY061 is located in the mountain range (Fig. 1) and thus the dominant frequency was almost $6 \mathrm{~Hz}$. KAU012 is located on the Gutingkeng Formations with a peak frequency of approximately $2.5 \mathrm{~Hz}$. CHY070 is located on the alluvium with a predominant frequency at approximately $1 \mathrm{~Hz}$, and this may be why its HVSR exhibited strong nonlinearity during the 2016 Meinong earthquake.

Figure 8 shows that the amplitude depression due to soil nonlinearity appeared at higher frequency of more than $10 \mathrm{~Hz}$ in most cases (e.g., CHY063 and CHY089). For such records, the influence of soil nonlinearity on EGF simulation is considered to be small relatively. In addition, Diao et al. (2018a, b) indicated that for the 2016 Meinong earthquake, the long-period velocity pulses of rupture-forward stations (e.g., CHY063 and CHY089) were mainly contributed by forward rupture directivity combined with an S-wave radiation pattern. Therefore, the following factors would lead to errors in synthetic waveforms: the inaccuracy of the focal mechanism, differences in the radiation patterns between the mainshock and EGF, and a nonlinear site response during the mainshock.

\section{Conclusions}

This study conducted an integrated analysis of the 2010 Jiashian and 2016 Meinong earthquakes using near-field strong-motion records, which helped us further investigate the site effects and responses to the earthquake source in this thick-mudstone-layer region. Our results revealed that both events exhibited rupture directivity corresponding with westward propagation. The 2010 Jiashian earthquake displayed a minimal directivity effect with up-dip rupture, whereas the 2016 Meinong event exhibited a stronger rupture directivity effect with leftlateral motion, and the high stress drops of deep ruptures might have strengthened the ground motion. The localized high PGV patch between the Hsinhua fault and Tsochen fault and the nonlinear site response could be attributed to the soft sediment with high pore fluid pressure and low-velocity structure beneath this region. The larger radiated energy and the closer rupture location to the thick-mudstone-layer region for the 2016 Meinong event, which reinforced the strong ground shaking and

\footnotetext{
(See figure on next page.)

Fig. 5 The observed peak ground velocity distribution and slip models of the 2010 Jiashian (Lee et al. 2013) and 2016 Meinong (Lee et al. 2016) events, respectively. The gray rectangles show the SMGA models of the 2010 Jiashian (blue star) and 2016 Meinong (green star) events, respectively, with black dots representing the rupture starting points. The crosses and squares represent the locations of damaged structures and liquefactions investigated by the Central Geological Survey, respectively. The regular and inverted triangles indicate strong-motion stations affected by the dominant frequency band of energy bursts in low-frequency band (LF, $\leq 1.67 \mathrm{~Hz})$ and high-frequency band $(\mathrm{HF},>1.67 \mathrm{~Hz})$, respectively
} 


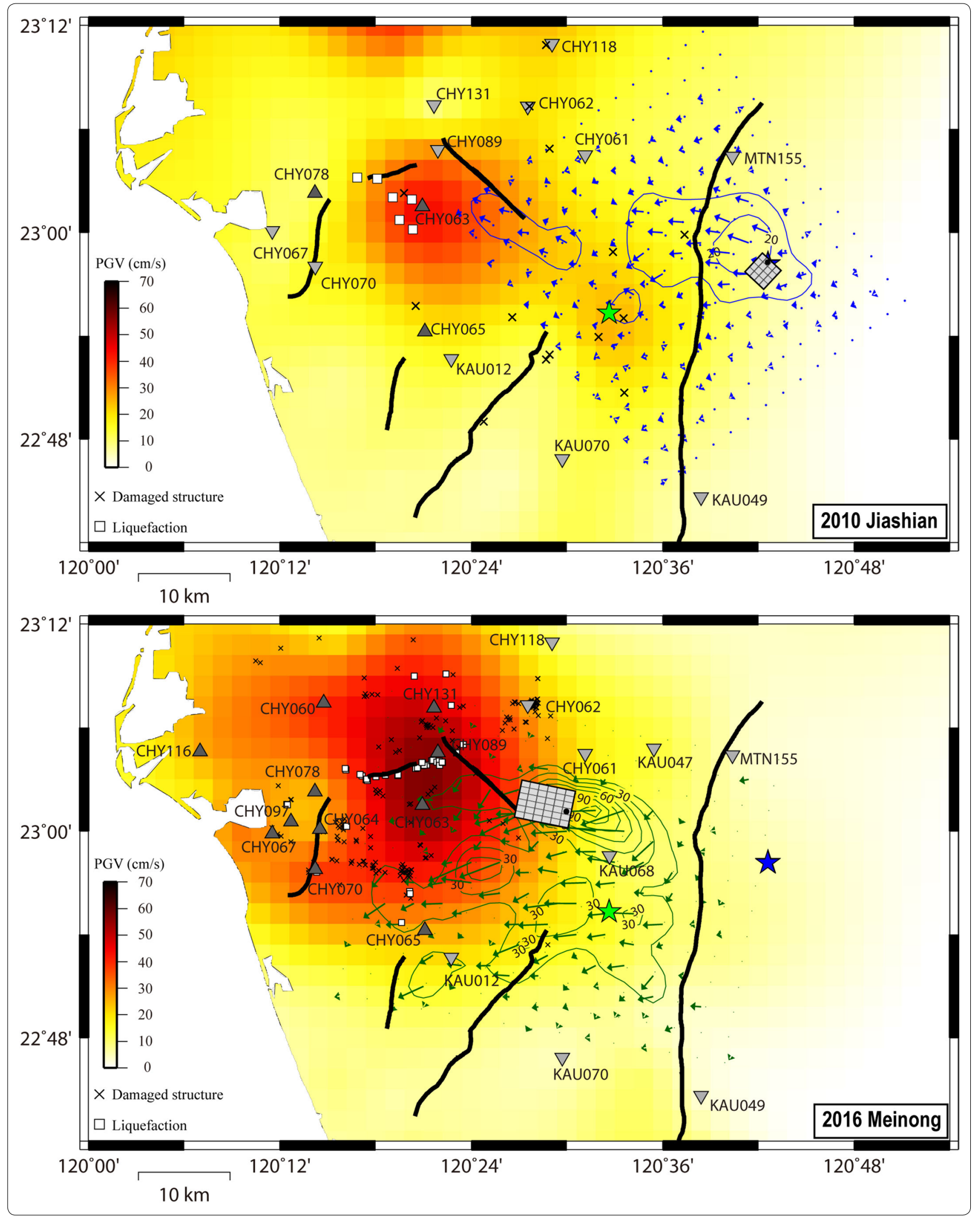




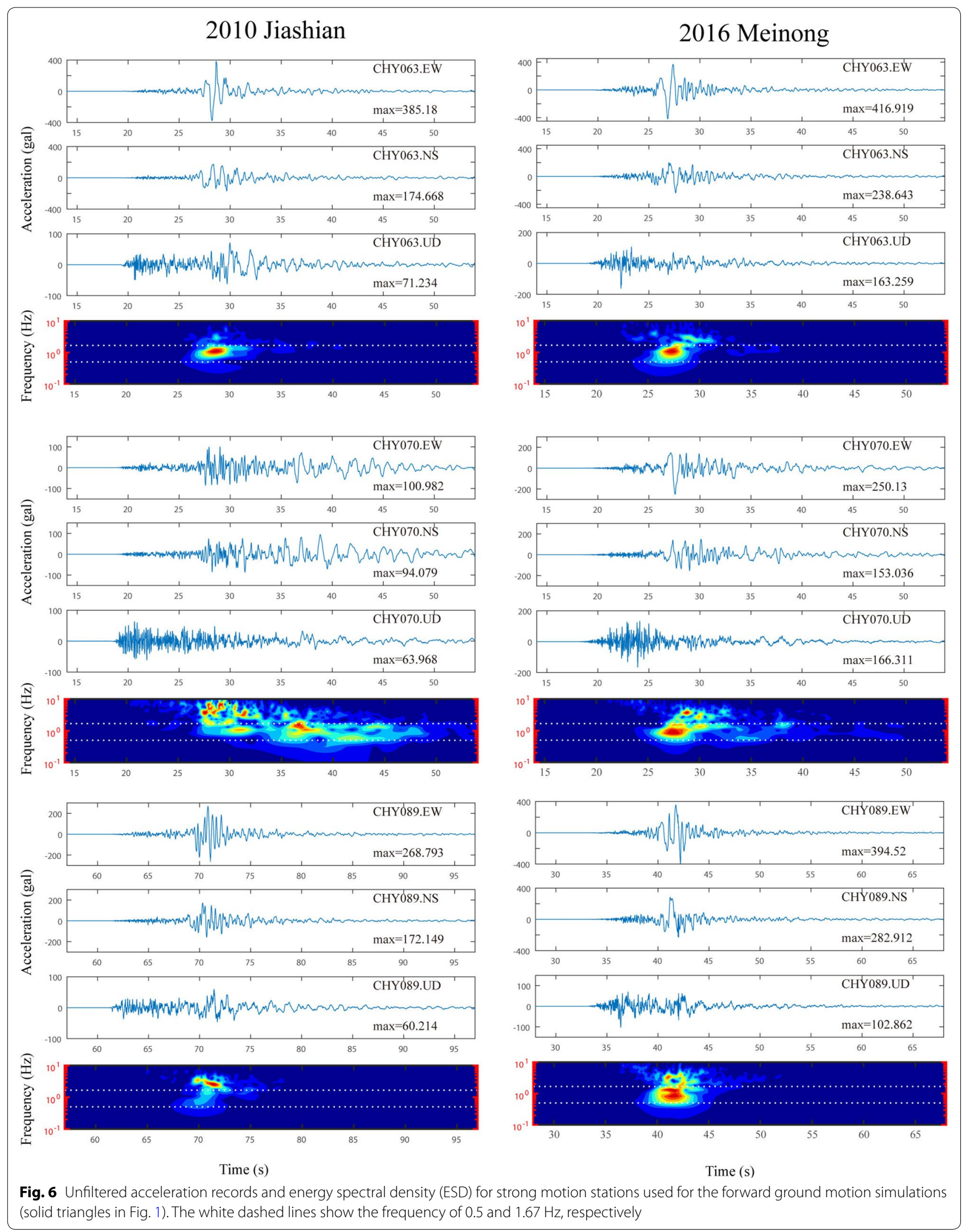




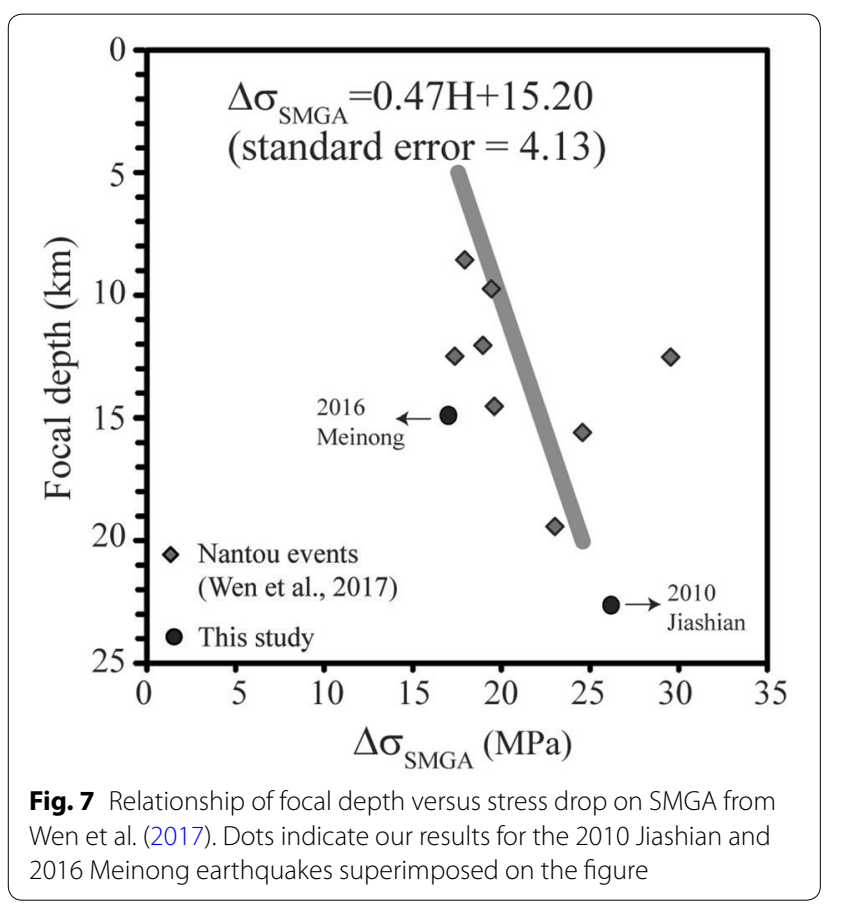

amplified the serious damage that was wrought over a broad area. This implies that this thick-mudstone-layer region in southern Taiwan plays a critical role in seismic hazards. A recent study by Takai et al. (2019) also found that the cause of destructive ground motion, which had a predominant period of $1-2 \mathrm{~s}$, during the $2018 \mathrm{Mw} 6.6$ Hokkaido eastern Iburi earthquake was nonlinear amplification by the shallow underground velocity structure. Thus, investigating the site effects of the mudstone layer in southern Taiwan is crucial because of its complex behavior and influence, and these factors should be considered to the application of seismic hazard mitigation.
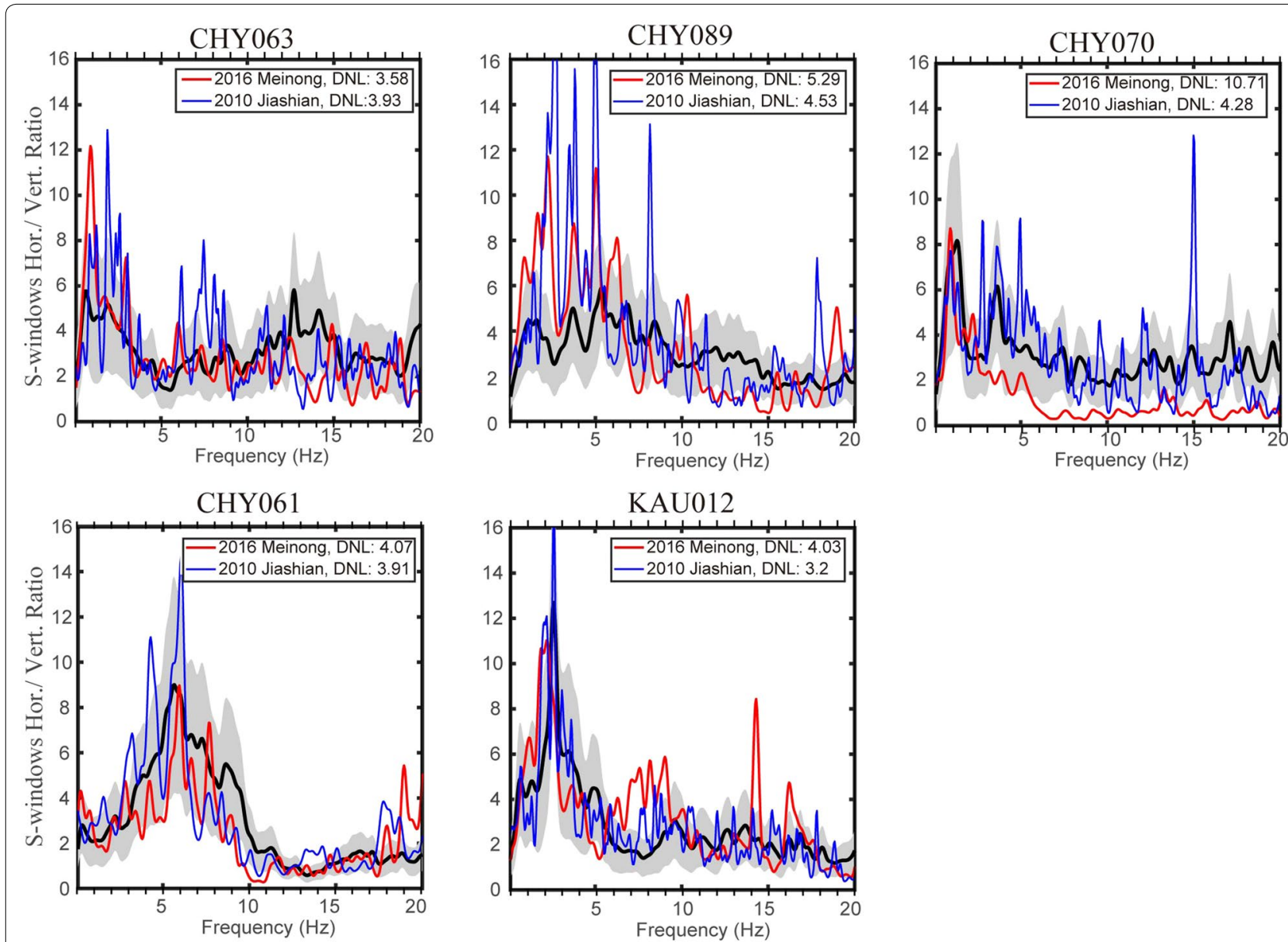

Fig. 8 HVSR for the 2010 Jiashian earthquake (blue line, this study), 2016 Meinong earthquake (red line; Chen et al. 2017) and weak motions (black line for mean value with shadowed areas showing the one standard deviation range; Chen et al. 2017) 


\section{Acknowledgements}

We thank the Geophysical Database Management System (GDMS), developed by the Central Weather Bureau (CWB) of Taiwan, and the Broadband Array in Taiwan for Seismology (BATS) for providing high-quality seismic data and focal mechanisms.

\section{Author contributions}

YYW performed the broadband strong motion simulation, stress drop and scaling relationship analyses and drafted the manuscript. CHK calculated the degree of non-linearity. YYW and YTY calibrated and improved the modeling results. YTY, CHK and KEC contributed to the discussion of the results. All authors participated in the discussion and the interpretation of the data. All authors read and approved the final manuscript.

\section{Funding}

This research was supported by the Ministry of Science and Technology in Taiwan with grant: MOST 109-2116-M-194-021 and MOST 108-2116-M-006017-MY2. The Taiwan Earthquake Center (TEC) contribution number for this article is 00166.

\section{Data availability}

Strong motion data was taken from the Geophysical Database Management System (GDMS), developed by Central Weather Bureau (CWB) of Taiwan at https://gdms.cwb.gov.tw/, and is available by request. The fault plane solutions and seismic moment were determined by Global Centroid Moment Tensor (CMT) at https://www.globalcmt.org/CMTsearch.html and the Broadband Array in Taiwan for Seismology (BATS) at http://tecws1.earth.sinica.edu.tw/ AutoBATS/.

\section{Ethics approval and consent to participate}

Not applicable.

\section{Consent for publication}

Not applicable.

\section{Competing interest}

The authors declare that they have no known competing financial interests or personal relationships that could have appeared to influence the work reported in this paper.

\section{Author details}

${ }^{1}$ Department of Earth and Environmental Sciences, National Chung Cheng University, Chia-yi County 62102, Taiwan. ${ }^{2}$ Environment and Disaster Monitoring Center, National Chung Cheng University, Chia-yi County 62102, Taiwan.

${ }^{3}$ Disaster Prevention Technology Research Center, Sinotech Engineering Consultants, Inc, Taipei 11494, Taiwan. ${ }^{4}$ Department of Earth Sciences, National Central University, Taoyuan City 32001, Taiwan. ${ }^{5}$ Department of Geomatics, National Cheng Kung University, Tainan 70101, Taiwan.

Received: 19 August 2020 Accepted: 25 November 2020 Published online: 09 December 2020

\section{References}

Aagaard BT, Hall JF, Heaton TH (2004) Effects of fault dip and slip rake angles on near-source ground motions: why rupture directivity was minimal in the 1999 Chi-Chi, Taiwan, earthquake. Bull Seismol Soc Am 94:155-170

Bard PY, Bouchon M (1985) The two-dimensional resonance of sediment field valleys. Bull Seismol Soc Am 75:519-541

Beresnev IA, Wen K-L (1996) Nonlinear site response-a reality? Bull Seismol Soc Am 86:1964-1978

Bonilla LF, Archuleta RJ, Lavallée D (2005) Hysteretic and dilatant behavior of cohesionless soils and their effects on nonlinear site response: field data observations and modeling. Bull Seismol Soc Am 95:2373-2395

Bonilla LF, Tsuda K, Pulido N, Regnier J, Laurendeau A (2011) Nonlinear site response evidence of K-NET and KiK-net records from the 2011 off the Pacific coast of Tohoku earthquake. Earth Planets Space 63:785-789

Boore DM, Seekins L, Joyner WB (1989) Peak accelerations from the 17 October 1989 Loma Prieta earthquake. Seismol Res Lett 60:151-166
Brune JN (1970) Tectonic stress and the spectra of seismic shear waves from earthquakes. J Geophys Res 75:4997-5009

Brune JN (1971) Correction. J Geophys Res 76:5002

Chan C-H, Wu Y-M (2012) A seismicity burst following the 2010 M6.4 Jiashian earthquake-implications for short-term seismic hazards in southern Taiwan. J Asian Earth Sci 59:231-239. https://doi.org/10.1016/j.jseae s.2012.08.011

Chen C-T (2019) Analysis of strong ground motion characteristics for the recent blind-fault earthquakes in southwestern Taiwan. Master Thesis, National Chung Cheng University, p 138 (in Chinese)

Chen C-T, Chang S-C, Wen K-L (2017) Stochastic ground motion simulation of the 2016 Meinong, Taiwan earthquake. Earth Planets Space. https://doi. org/10.1186/s40623-017-0645-Z

Chen Y-C, Huang H-C, Iwata T, Asano K (2019) Strong ground motion simulation of $2016 M_{\perp} 6.6$ Meinong, Taiwan, earthquake using the empirical Green's function method. J Geophys Res 124(12):12905-12919. https:// doi.org/10.1029/2019JB017661

Cotton F, Archuleta R, Causse M (2013) What is sigma of the stress drop? Seismol Res Lett 84:42-48. https://doi.org/10.1785/0220120087

Diao H, Kobayashi H, Koketsu K (2018) Rupture process of the 2016 Meinong, Taiwan, earthquake and its effects on strong ground motions. Bull Seismol Soc Am 108:163-174

Diao H, Miyake H, Koketsu K (2018) Near-fault broadband ground-motion simulations of the 2016 Meinong, Taiwan, earthquake. Bull Seismol Soc Am 108:3336-3357

Huang I-J (2013) Study of the relationship between surface rupture and faulting in relation to Jiashian earthquake. M.Sc. thesis, National Central University, Taiwan, p 115 (in Chinese with English abstract)

Huang S-T et al (2004) Deformation front development at the northeast margin of the Tainan basin, Tainan-Kaohsiung area Taiwan. Marine Geophys Res 25:139-156

Huang M-H, Dreger D, Burgmann R, Yoo S-H, Hashimoto M (2013) Joint inversion of seismic and geodetic data for the source of the 2010 March 4, Mw 6.3 Jia-Shian, SW Taiwan, earthquake. Geophys J Int 193:1608-1626. https://doi.org/10.1093/gji/ggt058

Huang H-H, Wu Y-M, Song X, Chang C-H, Lee S-J, Chang T-M, Hsieh H-H (2014) Joint Vp and Vs tomography of Taiwan: implications for subduction-collision orogeny. Earth Planet Sci Lett 392:177-191. https ://doi.org/10.1016/j.epsl.2014.02.026

Huang $\mathrm{M}-\mathrm{H}$, Tung $\mathrm{H}$, Fielding EJ, Huang $\mathrm{H}-\mathrm{H}$, Liang $\mathrm{C}$, Huang $\mathrm{C}$, Hu J-C (2016) Multiple fault slip triggered above the $2016 M_{w} 6.4$ MeiNong earthquake in Taiwan. Geophys Res Lett 43:7459-7467. https://doi. org/10.1002/2016GL069351

lai S, Morita T, Kameoka T, Matsunaga Y, Abiko K (1995) Response of a dense sand deposit during 1993 Kushiro-Oki earthquake. Soils Found 35:115131. https://doi.org/10.3208/sandf1972.35.115

Irikura K (1986) Prediction of strong acceleration motions using empirical Green's function. In: Proceeding of 7th Japan earthquake engineering symp, Tokyo, 10-12 December 1986, pp 151-156

Irikura K, Kamae K (1994) Estimation of strong ground motion in broad-frequency band based on a seismic source scaling model and an empirical Green's function technique. Ann Geophys 37:1721-1743

Kagawa T, Irikura K, Somerville PG (2004) Differences in ground motion and fault rupture process between the surface and buried rupture earthquakes. Earth Planets Space 56:3-14. https://doi.org/10.1186/BF03352486

Kanamori H, Ye L, Huang B-S, Huang H-H, Lee S-J, Liang W-T, Lin Y-Y, Ma K-F, Wu Y-M, Yeh T-Y (2017) A strong-motion hot spot of the 2016 Meinong, Taiwan, earthquake $\left(M_{w}=6.4\right)$. Terr Atmos Ocean Sci 28:637-650

Kuo C-H, Wen K-L, Hsieh H-H, Lin C-M, Chang T-M, Kuo K-W (2012) Site classification and Vs30 estimation of free-field TSMIP stations using the logging data of EGDT. Eng Geol 129-130:68-75

Kuo C-H, Lin C-M, Chang S-C, Wen K-L, Hsieh H-H (2017) Site database for Taiwan strong motion stations. Technical Report of NCREE, National Center for Research on Earthquake Engineering, NCREE-17-004

Kuo-Chen H, Chen K-X, Sun W-F, Ho C-W, Lee Y-H, Guan Z-K, Kang C-C, Chang W-Y (2017) 3D Vs ambient noise tomography of the $2016 \mathrm{M}_{w}$ 6.4 Meinong earthquake source region in Taiwan. Terr Atmos Ocean Sci 28:693-701

Lee S-J, Liang W-T, Mozziconacci L, Hsu Y-J, Huang W-G, Huang B-S (2013) Source complexity of the 4 March 2010 Jiashian, Taiwan earthquake 
determined by joint inversion of teleseismic and near field data. J Asian Earth Sci 64:14-26

Lee S-J, Yeh T-Y, Lin Y-Y (2016) Anomalously large ground motion in the 2016 $M_{L} 6.6$ Meinong, Taiwan, earthquake: a synergy effect of source rupture and site amplification. Seismol Res Lett 87:1319-1326. https://doi. org/10.1785/0220160082

Lin Y-Y, Yeh T-Y, Ma K-F, Song T-RA, Lee S-J, Huang B-S, Wu Y-M (2018) Source characteristics of the 2016 Meinong (ML 6.6), Taiwan, earthquake, revealed from dense seismic arrays: double sources and pulse-like velocity ground motion. Bull Seismol Soc Am 108:188-199. https://doi. org/10.1785/0120170169

Miyake H, Iwata T, Irikura K (1999) Strong ground motion simulation and source modeling of the Kagoshima-ken Hokuseibu earthquakes of March 26 ( $M_{\text {JMA }} 6.5$ ) and May 13 (M MMA 6.3), 1997, using empirical Green's function method. Zisin 51:431-442 (in Japanese with English abstract)

Miyake H, Iwata T, Irikura K (2001) Estimation of rupture propagation direction and strong motion generation area from azimuth and distance dependence of source amplitude spectra. Geophys Res Lett 28:2727-2730

Miyake H, Iwata T, Irikura K (2003) Source characterization for broadband ground-motion simulation: kinematic heterogeneous source model and strong motion generation area. Bull Seismol Soc Am 93:2531-2545

Poiata N, Koketsu K, Vuan A, Miyake H (2012) Lowfrequency and broadband source models for the 2009 L'Aquila, Italy, earthquake. Geophys J Int 191:224-242

Poiata N, Miyake H, Koketsu K (2017) Mechanism for generation of nearfault ground motion pulses for dip-slip faulting. Pure Appl Geophys 174:3521-3536. https://doi.org/10.1007/s00024-017-1540-z

Radiguet M, Cotton F, Manighetti I, Campillo M, Douglas J (2009) Dependency of near-field ground motions on the structural maturity of the ruptured faults. Bull Seismol Soc Am 99:2572-2581

Rau R-J (2017) The 2016 Meinong Kaohsiung earthquake_-post earthquake scientific investigation. MOST Report, Ministry of Science and Technology, $\mathrm{ROC}$ (in Chinese)

Rau R-J, Wu F-T (1995) Tomographic imaging of lithospheric structures under Taiwan. Earth Planet Sci Lett 133:517-532

Shin T-C, Chang C-H, Pu H-C, Lin H-W, Leu P-L (2013) The geophysical database management system in Taiwan. Terr Atmos Ocean Sci 24:11-18

Somerville PG (2003) Magnitude scaling of the near fault rupture directivity pulse. Phys Earth Planet Int 137:201-212

Somerville PG, Smith NF, Graves RW, Abrahamson NA (1997) Modification of empirical strong ground motion attenuation relations to include the amplitude and duration effects of rupture directivity. Seismol Res Lett 68:199-222

Somerville P, Irikura K, Graves R, Sawada S, Wald D, Abrahamson N, Iwasaki Y, Kagawa T, Smith N, Kowada A (1999) Characterizing crustal earthquake slip models for the prediction of strong ground motion. Seismol Res Lett 70:59-80

Stockwell RG, Mansinha L, Lowe RP (1996) Localization of the complex spectrum: the S transform. IEEE Trans Signal Process 44:998-1001

Sung $\mathrm{Y}-\mathrm{C}$, Lee $\mathrm{C}-\mathrm{H}$, Lin $\mathrm{F}-\mathrm{R}$, Lin $\mathrm{K}-\mathrm{C}$, Lin C-M, Hung H-H, Chai C-F, Wong P-W, Chang Y-W, Chang J-J, Hwang S-J, Huang Y-T, Yang Y-S, Liou K-Y, Kuo K-C, Chen C-Y, Chen W-C, Chen W-C, Jean W-Y, Su C-K (2010) Reconnaissance report on Jiaxian earthquake in Kaohsiung on March 4, 2010. NCREE Report No. NCREE-10-010, National Center for Research on Earhtquake Engineering (in Chinese)

Takai N, Shigefuji M, Horita J et al (2019) Cause of destructive strong ground motion within 1-2 s in Mukawa town during the $2018 M_{w} 6.6$ Hokkaido eastern Iburi earthquake. Earth Planets Space. https://doi.org/10.1186/ s40623-019-1044-4

Velasco AA, Ammon CJ, Lay T (1994) Empirical Green function deconvolution of broadband surface waves: rupture directivity of the 1992 Landers, California $\left(M_{w}=7.3\right)$ earthquake. Bull Seismol Soc Am 84:735-750

Wen Y-Y, Chen C-C, Wu Y-H, Chan C-H, Wang Y-J, Yeh Y-L (2016) Spatiotemporal investigation of seismicity and Coulomb stress variations prior to the 2010 M 6.4 Jiashian, Taiwan earthquake. Geophys Res Lett 43:8451-8457. https://doi.org/10.1002/2016GL070633

Wen Y-Y, Chao S-Y, Yen Y-T, Wen S (2017) Source characteristics of moderateto-strong earthquakes in the Nantou area, Taiwan: insight from strong ground motion simulations. Earth Planets Space. https://doi.org/10.1186/ s40623-017-0720-5

Wu Y-M, Lin T-L, Chao W-A, Huang H-H, Hsiao N-C, Chang C-H (2011) Faster short-distance earthquake early warning using continued monitoring of filtered vertical displacement-a case study for the 2010 Jiasian earthquake, Taiwan. Bull Seismol Soc Am 101:701-709. https://doi. org/10.1785/0120100153

Wu Y-M, Liang W-T, Mittal H, Chao W-A, Lin C-H, Huang B-S, Lin C-M (2016) Performance of a low-cost earthquake early warning system (P-alert) during the $2016 M_{\perp} 6.4$ Meinong (Taiwan) earthquake. Seismol Res Lett 87:1050-1059. https://doi.org/10.1785/0220160058

Yuan J, Huang S-T, Chou T-F, Wu J-C, Lu D-L (1987) The origin of the abnormal pressure zones in Southwestern Taiwan. Annu Explor Prod (CPC) 10:1-27 (in Chinese)

\section{Publisher's Note}

Springer Nature remains neutral with regard to jurisdictional claims in published maps and institutional affiliations.

\section{Submit your manuscript to a SpringerOpen ${ }^{\circ}$ journal and benefit from:}

- Convenient online submission

- Rigorous peer review

- Open access: articles freely available online

- High visibility within the field

Retaining the copyright to your article

Submit your next manuscript at $\boldsymbol{\nabla}$ springeropen.com 